\title{
Pollen Sources used by Tetragonisca angustula (Latreille, 1811) (Apidae, Meliponini) in the Atlantic Forest, Northern Coast of Bahia
}

\author{
BP BASTOS ${ }^{1}$, LCL LIMA², MC DÓREA ${ }^{1}$ \\ 1 - Universidade Estadual de Feira de Santana (UEFS), Programa de Pós-graduação em Botânica, Feira de Santana, Bahia, Brazil \\ 2 - Universidade do Estado da Bahia (UNEB), Campus Alagoinhas, Bahia, Brazil
}

\section{Article History}

\section{Edited by}

Evandro Nascimento Silva, UEFS, Brazil

Received

08 July 2020

Initial acceptance 15 October 2020

Final acceptance 18 November 2020

Publication date 28 December 2020

\section{Keywords}

Stingless bees, melissopalinology, pollenpot, bee flora, trophic resources.

\section{Corresponding author}

Brenna P. Bastos

(iD) https://orcid.org/0000-0003-1711-2052 Universidade Estadual de Feira de Santana Programa de Pós-graduação em Botânica, LABIO, Campus Universitário

Av. Transnordestina s/no, Novo Horizonte CEP 44.036-900, Feira de Santana-BA, Brasil. E-Mail: brennabastos@hotmail.com

\begin{abstract}
Stingless bees are important floral visitors in tropical ecosystems and through pollination, play a key role in maintaining biodiversity and perpetuating native plant species. In this context, knowledge about the flora used by stingless bees is essential to promote their conservation in natural environments. This study had the objective of analyzing the pollen stored by Tetragonisca angustula (Latreille, 1811 ) in an Atlantic Forest area. A total of 27 pollen samples were collected from six colonies from April 2013 to March 2014. The samples were processed using acetolysis, in which pollen types were identified, photomicrographs and their frequency values were estimated. The most representative pollen types had their pollen morphology described. The analysis of the pollen sediment revealed 53 pollen types, three of which were indeterminate and the others belonged to 26 families. Among the registered pollen types, only 13 (distributed in ten families) showed frequency values over $10 \%$ in the analyzed samples, in which the majority presented a pollen morphology classified as microreticulated and tricolporate small monads. The pollen types Byrsonima (with frequency between 0.05 to $82.79 \%$, which was recorded throughout the entire study period), Tapirira guianensis (0.92 to $55.65 \%$ ), and Cecropia ( 0.24 to $49.32 \%$ ), stood out as an important source of trophic resources for the maintenance and survival of $T$. angustula in an Atlantic Forest area. In addition, this study highlights the importance of palynological analysis for the knowledge of trophic resources used by stingless bees.
\end{abstract}

\section{Introduction}

In tropical ecosystems, stingless bees (Meliponini) are considered the most efficient pollinators and play a key role in maintaining native plant communities. However, the degradation of natural environments over the years, as a consequence of the significant loss of habitat, climate changes, use of pesticides, and the introduction of exotic species, has led to a decline in populations of native pollinators (Burkle \& Alarcón, 2011; Giannini et al., 2012; Potts et al., 2016).

Stingless bees, or meliponines, are organized in permanent colonies that can contain numerous individuals, ranging from a few dozen to more than 100,000 workers, and have a pantropical distribution with great diversity, especially in the neotropics (Michener, 2007). In Brazil, hundreds of species of stingless bees have been described (Pedro, 2014), among which Tetragonisca angustula (Latreille, 1811) stands out as one of the most popular and bred species. Popularly known as Jataí, it presents generalist habits and expressive pollination service in tropical flora, as well as in agricultural crops (Antunes et al., 2007; Giannini et al., 2014).

Knowledge about the flora used by stingless bees is essential to favor their conservation and maintenance in natural environments, and, to contribute to the sustainable exploitation of their products through meliponiculture (Kerr, 1997; Giannini et al., 2015). In this context, palynological 
studies are an important tool for identification of the origin of the floral sources visited by bees to collect trophic resources. The northeastern region of Brazil has stood out in the production of melissopalinological studies (Souza et al., 2018). However, further research that reflects the local flora used by stingless bees in the Atlantic Forest is needed since it is widely diversified (Oliveira-Filho \& Fontes, 2000).

In order to fill gaps in the knowledge about the local flora of importance to stingless bees in an Atlantic Forest area, the present study aimed to characterize the pollen stored by $T$. angustula, evaluating the importance of pollen types and describing the pollen morphology of the most exploited pollen grains.

\section{Material and Methods}

Study area

The research was conducted in a fragment of Atlantic Forest with approximately 50 hectares, located on Campus II of the Universidade do Estado da Bahia (UNEB), municipality of Alagoinhas - BA (1208'08'S; 38 $25^{\circ}$ '09'W - Fig. 1 and 2 ), in the Território de Identidade Litoral Norte e Agreste Baiano. The area presents a humid to sub-humid climatic type, mean annual temperature of $23^{\circ} \mathrm{C}$, altitude of $132 \mathrm{~m}$, annual precipitation of $1234.1 \mathrm{~mm}$ and rainy period from
March to July (Superintendência de Estudos Econômicos e Sociais da Bahia [SEI], 2018).

According to Jesus et al. (2017), the landscape is characterized by a remnant vegetation cover of Dense Submontane Rainforest with a distinct phytophysiognomies due to the strong edaphoclimatic influence of the area. The most representative botanical families are Fabaceae, Asteraceae, Myrtaceae, Rubiaceae, and Poaceae.

\section{Sample collection}

Pollen samples were collected from six colonies of Tetragonisca angustula (Latreille, 1811), which were checked monthly from April 2013 to March 2014. Pollen samples (between 1 to 3 grams) were collected directly in a new storage pot in each colony, recognized by the light color of the cerumen lamellae (Cortopassi-Laurino \& Ramalho, 1988). However, in some colonies, it was not possible to remove pollen samples for 12 consecutive months, as a small amount of the resource was evidenced within the colony, and its removal could cause a shortage of protein food for bees. Thus, a total of 27 pollen samples were collected, and afterwards were processed and analyzed at the Laboratório de Micromorfologia Vegetal of Universidade Estadual of Feira de Santana (LAMIV/UEFS).

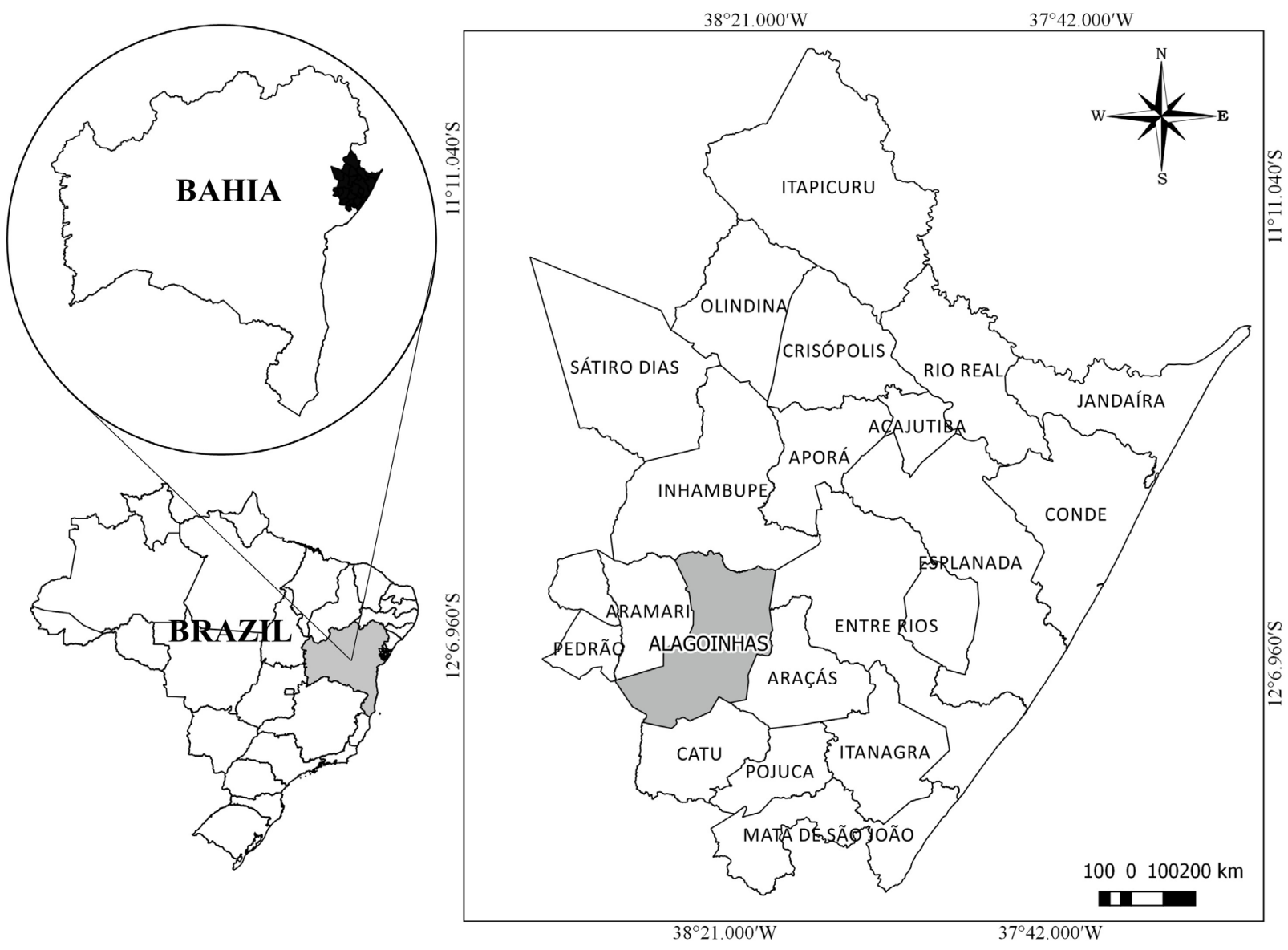

Fig 1. Location of the Território de Identidade Litoral Norte e Agreste Baiano, with emphasis on the municipality of Alagoinhas - BA, Brazil. 

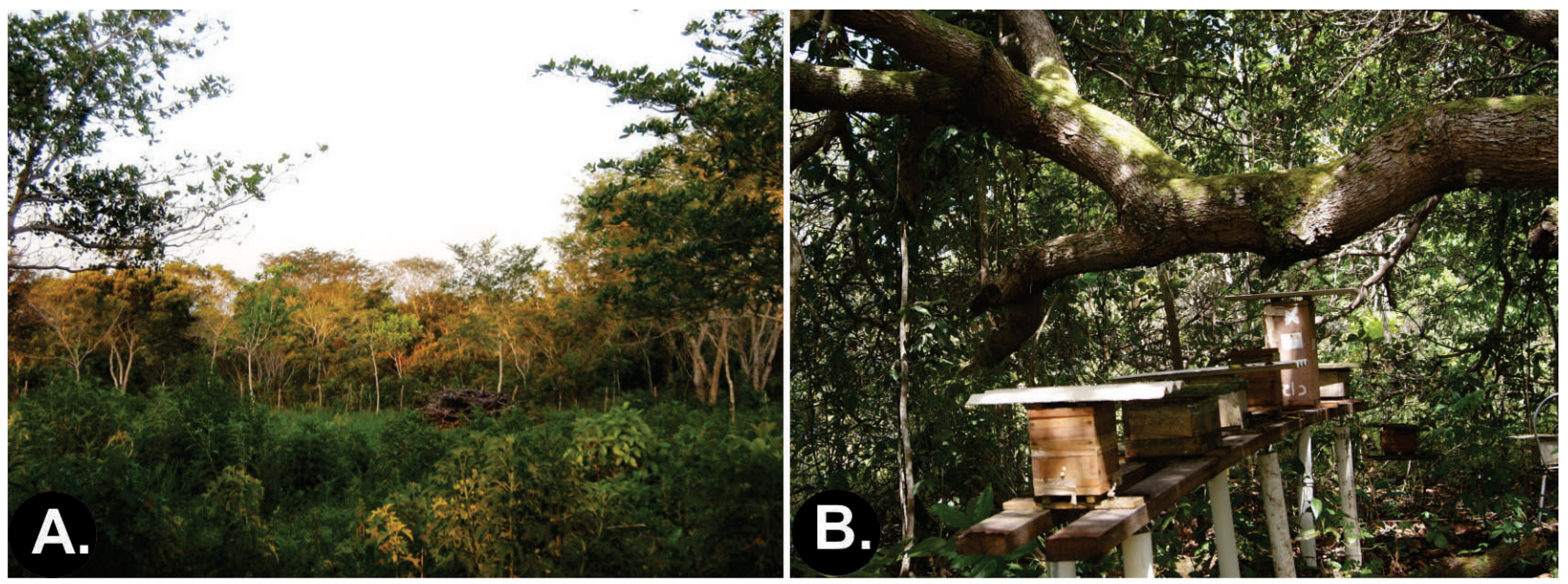

Fig 2. Study area. (A) General physiognomy of the local vegetation. (B) Meliponary implanted in an Atlantic Forest area.

\section{Processing and analysis of samples}

The processing of pollen samples consisted of the dilution of 1 to 2 grams of pollen in twice of the weight of hot water, mixing and stirring for a few minutes, allowing it to rest for 2 hours. Subsequently, the material is centrifuged, and the supernatant is discarded (Louveaux et al., 1978; Iwama \& Melhem, 1979).

Afterwards, the pollen sediment was subjected to the acetolysis technique (Erdtman, 1960), and five slides were prepared in glycerin gelatin for each sample, one of which was stained with safranin, and sealed with fused histological paraffin. A complete scanning of the slides was initially carried out with the purpose of determining all the pollen types present, considering that those pollen grains that appear with low frequency in the samples may not be detected at the time of counting. Pollen grains were identified according to the concept of pollen types proposed by Joosten and De Klerk (2002) and De Klerk and Joosten (2007). Thus, pollen grains were determined from comparison with the pollen library at LAMIV/UEFS and specialized pollen catalogs, and through consulting the list of species occurring in the study area to describe the growing habit of taxa related to the identified pollen types (Jesus et al., 2017). In each sample, a minimum of 1,000 pollen grains were counted to estimate the frequency values (Vergeron, 1964). The frequency of occurrence in the samples, which assesses the presence and absence of pollen types through the months of the study period, was established according to the following classes (Jones \& Bryant Jr., 1996): very frequent (> 50\%); frequent (20 to $50 \%$ ); uncommon (10 to $<20 \%)$ and rare $(<10 \%)$. To establish pollen frequency, the data obtained through the analysis of pollen material were grouped and interpreted monthly, during the study period.

The main morphometric parameters of pollen types were measured aiming to understand if any characteristic of the pollen morphology is common among the identified pollen types. For this, only pollen types with frequency values above $10 \%$ in the samples were considered, as they were considered as important sources of food (Ramalho et al., 1985).
The analysis was performed according to the technical recommendations indicated by Salgado-Labouriau (1973) and Melhem et al. (1984). For the description of the pollen grains, the smallest and largest diameter, as well as the equatorial diameter in polar view were measured whenever possible in 25 pollen units chosen at random. Also, the ornamentation patterns of the pollen surface were analyzed. The quantitative results were analyzed through the appropriate statistical analysis: The arithmetic mean, standard deviation of the mean and the range of variation were calculated. The illustrations necessary for the characterization of pollen grains were obtained from photomicrographs performed in a Zeiss Axio Scope.A1 microscope adapted to image capture camera. Finally, all the palynological descriptions followed the terminology of Punt et al. (2007).

The entire assembled laminar was deposited in the pollen library at LAMIV/UEFS, with duplicates deposited in the pollen library at Laboratório de Estudos Palinológicos of the Universidade do Estado da Bahia - Campus II.

\section{Results}

From the microscopic analysis of the sediment from the pollen mass, it was possible to identify 53 pollen types, of which 50 belonged to 26 botanical families and three types could not be determined. The families with the greatest contribution to diversity of pollen types were Fabaceae (9), Asteraceae (5), and Rubiaceae (5), respectively. Of the total pollen types recorded, five were not evidenced in the quantitative analysis, namely: Dicliptera (Acanthaceae), Commelina erecta (Commelinaceae), Hyptis pectinata (Lamiaceae), Richardia grandiflora (Rubiaceae), and indeterminate III. During the study period, there was a monthly average of 21 pollen types (Table 1), where the lowest richness was recorded in May/2013 (16) and February/2014 (16) and the highest in December/2013 (29).

Quantitative analysis was performed on 48 pollen types (Table 1). It was observed that most of the pollen types (approximately 69\%) were classified as frequent (21) and 
very frequent (12) during the study period. In addition, it was found that pollen types were more frequently related to plant species of shrubby habit (44.2\%), followed by arboreal $(30.8 \%)$ and herbaceous $(21.2 \%)$, being the liana habit $(3.8 \%)$ the least representative in our results. However, there were pollen types that were associated with taxa that present more than one growing habit, such as Caesalpinia, which represents both arboreal and shrubby plants.

Table 1. Relative frequency (\%) and classes of frequency of occurrence (FO) of pollen types occurring in pollen samples stored by Tetragonisca angustula (Latreille, 1811) in an Atlantic Forest area on the northern coast of Bahia. FO: Very Frequent (VF: $>50 \%)$, Frequent (F: 20\% - 50\%), Infrequent (I: $10 \%-<20 \%$ ) and Rare (R: $<10 \%)$. Habit (Hab) of plant species related to pollen types $-\mathrm{A}=\mathrm{Arboreal}$; $\mathrm{S}=\mathrm{Shrubby}$; $\mathrm{H}=$ Herbaceous; $\mathrm{L}=$ Liana.

\begin{tabular}{|c|c|c|c|c|c|c|c|c|c|c|c|c|c|c|}
\hline \multirow{2}{*}{ Pollen Type } & \multicolumn{9}{|c|}{2013} & \multicolumn{3}{|c|}{2014} & \multirow{2}{*}{ FO } & \multirow{2}{*}{ Hab } \\
\hline & Apr. & May & June & July & Aug. & Sept. & Oct. & Nov. & Dec. & Jan. & Feb. & Mar. & & \\
\hline \multicolumn{15}{|l|}{ AMARANTHACEAE } \\
\hline Amaranthus viridis & 0.08 & & 1.42 & 1.23 & & & 0.84 & & & & & & $\mathrm{~F}$ & $\mathrm{H}$ \\
\hline Alternanthera brasiliana & & & 0.04 & 0.34 & & & 11.38 & 0.03 & 0.03 & & & & $\mathrm{~F}$ & $\mathrm{H}$ \\
\hline \multicolumn{15}{|l|}{ ANACARDIACEAE } \\
\hline Anacardium occidentale & 41.78 & 24.09 & & 22.32 & & 3.09 & & 2.68 & 0.96 & & 13.27 & 10.18 & $\mathrm{VF}$ & A \\
\hline Spondias tuberosa & & 0.43 & 0.74 & 0.16 & 2.13 & 0.39 & & 0.06 & 0.37 & 1.19 & 4.30 & 2.91 & VF & A \\
\hline Tapirira guianensis & 41.12 & 17.93 & 55.65 & 3.14 & 0.92 & 1.16 & 4.71 & 6.30 & & 36.89 & 27.64 & 41.55 & $\mathrm{VF}$ & A \\
\hline \multicolumn{15}{|l|}{ ARECACEAE } \\
\hline Cocos nucifera & & & & & & & & & & & & 0.14 & $\mathrm{R}$ & A \\
\hline \multicolumn{15}{|l|}{ ASTERACEAE } \\
\hline Aspilia & 0.12 & & 2.66 & 17.70 & & 27.80 & 0.31 & 0.03 & & & & & $\mathrm{~F}$ & S \\
\hline Baccharis retusa & & 2.36 & 9.43 & 20.76 & 0.12 & 6.28 & 3.87 & & & 0.33 & 0.32 & 1.41 & VF & $\mathrm{S}$ \\
\hline Tridax procumbens & & & & & & & & & & & & 0.05 & $\mathrm{R}$ & $\mathrm{H}$ \\
\hline Verbesina macrophylla & & & & 3.22 & 0.40 & 1.68 & & 0.64 & & & & & $\mathrm{~F}$ & $\mathrm{~S}$ \\
\hline Vernonanthura brasiliana & & & 0.04 & & & & 0.40 & & & & & & I & $\mathrm{S}$ \\
\hline \multicolumn{15}{|l|}{ CANNABACEAE } \\
\hline Celtis & & 0.39 & & & 0.56 & & 17.70 & 35.19 & 2.52 & 4.65 & 0.23 & 1.18 & $\mathrm{VF}$ & A \\
\hline \multicolumn{15}{|l|}{ CLEOMACEAE } \\
\hline Tarenaya aculeata & & & 6.74 & & & 2.45 & 6.67 & 0.06 & & 0.05 & & & $\mathrm{~F}$ & $\mathrm{H}$ \\
\hline \multicolumn{15}{|l|}{ COMMELINACEAE } \\
\hline Commelina & & & 9.75 & 2.05 & & 7.72 & & 0.06 & & & 0.05 & & $\mathrm{~F}$ & $\mathrm{H}$ \\
\hline \multicolumn{15}{|l|}{ EUPHORBIACEAE } \\
\hline Croton campestres & 0.04 & & & & & & & & & & & & $\mathrm{R}$ & $\mathrm{S}$ \\
\hline Ricinus communis & & & & & & & 5.51 & 0.61 & & & & & I & $\mathrm{S}$ \\
\hline \multicolumn{15}{|l|}{ FABACEAE } \\
\hline Aeschynomene paniculata & & & & & & & 7.07 & 1.79 & 1.27 & 0.43 & 12.59 & 7.41 & $\mathrm{~F}$ & $\mathrm{~S}$ \\
\hline Bauhinia & 0.04 & & & & & & & & & & & & $\mathrm{R}$ & A \\
\hline Caesalpinia & 0.35 & 0.97 & 0.46 & 0.10 & 0.24 & 0.11 & 0.58 & 0.15 & 1.40 & & 0.09 & 0.05 & $\mathrm{VF}$ & $\mathrm{S} / \mathrm{A}$ \\
\hline Caesalpinia pulcherrima & & & 0.04 & & & & & & & & & & $\mathrm{R}$ & $\mathrm{S} / \mathrm{A}$ \\
\hline Dioclea & & & & & & & & 3.01 & 0.53 & 0.09 & & & $\mathrm{~F}$ & $\mathrm{~S} / \mathrm{L}$ \\
\hline Leucaena leucocephala & 0.31 & & & & & & & & & & & & $\mathrm{R}$ & S \\
\hline Mimosa pudica & & & & 0.44 & 0.32 & & 14.18 & 0.03 & & & & & $\mathrm{~F}$ & $\mathrm{~S}$ \\
\hline Mimosa quadrivalvis & & 0.02 & 0.46 & 2.05 & 0.04 & & 0.27 & & & & & & $\mathrm{~F}$ & $\mathrm{H}$ \\
\hline $\begin{array}{l}\text { Stryphnodendron } \\
\text { pulcherrimum }\end{array}$ & & 0.27 & 0.07 & 0.02 & 0.08 & & & & & 0.05 & & & $\mathrm{~F}$ & A \\
\hline \multicolumn{15}{|l|}{ LORANTHACEAE } \\
\hline Psittacanthus & & 0.05 & 0.04 & & & & & 0.03 & & & & 0.05 & $\mathrm{~F}$ & $\mathrm{H}$ \\
\hline \multicolumn{15}{|l|}{ MALPIGHIACEAE } \\
\hline Byrsonima & 8.75 & 48.59 & 5.28 & 20.99 & 82.79 & 29.07 & 6.85 & 3.86 & 39.01 & 41.92 & 0.05 & 0.50 & VF & A \\
\hline
\end{tabular}


Table 1. Relative frequency (\%) and classes of frequency of occurrence (FO) of pollen types occurring in pollen samples stored by Tetragonisca angustula (Latreille, 1811) in an Atlantic Forest area on the northern coast of Bahia. FO: Very Frequent (VF: $>50 \%$ ), Frequent (F: 20\% - 50\%), Infrequent (I: $10 \%-<20 \%$ ) and Rare (R: $<10 \%)$. Habit (Hab) of plant species related to pollen types $-\mathrm{A}=\mathrm{Arboreal}$; $\mathrm{S}=\mathrm{Shrubby}$; $\mathrm{H}=$ Herbaceous; $\mathrm{L}=$ Liana. (Continuation)

\begin{tabular}{|c|c|c|c|c|c|c|c|c|c|c|c|c|c|c|}
\hline \multirow{2}{*}{ Pollen Type } & \multicolumn{9}{|c|}{2013} & \multicolumn{3}{|c|}{2014} & \multirow{2}{*}{ FO } & \multirow{2}{*}{ Hab } \\
\hline & Apr. & May & June & July & Aug. & Sept. & Oct. & Nov. & Dec. & Jan. & Feb. & Mar. & & \\
\hline \multicolumn{15}{|l|}{ MALVACEAE } \\
\hline Sida cordifolia & & & & & & & 0.27 & & & & & 0.50 & I & $\mathrm{S}$ \\
\hline \multicolumn{15}{|l|}{ MELASTOMATACEAE } \\
\hline Miconia & 4.22 & 0.05 & & & & & 8.27 & 1.52 & 0.34 & 0.19 & & 1.23 & $\mathrm{VF}$ & $\mathrm{S} / \mathrm{A}$ \\
\hline \multicolumn{15}{|l|}{ MOLLUGINACEAE } \\
\hline Mollugo verticillata & 0.16 & & & & & & & & & & & & $\mathrm{R}$ & $\mathrm{H}$ \\
\hline \multicolumn{15}{|l|}{ MYRTACEAE } \\
\hline Eucalyptus & 0.16 & 4.22 & & 0.62 & 10.87 & & & 1.22 & & & & & $\mathrm{~F}$ & A \\
\hline Myrcia & & & & & & 2.01 & & & 3.70 & 2.18 & & 1.64 & $\mathrm{~F}$ & $\mathrm{~S}$ \\
\hline \multicolumn{15}{|l|}{ PIPERACEAE } \\
\hline Piper divaricatum & & & 2.59 & & 0.04 & & & & 0.06 & & & & $\mathrm{~F}$ & $\mathrm{~S}$ \\
\hline \multicolumn{15}{|l|}{ PLANTAGINACEAE } \\
\hline Stemodia foliosa & 0.08 & 0.18 & & & 0.04 & 0.11 & & & 0.06 & 0.66 & 0.92 & 11.14 & VF & $\mathrm{S} / \mathrm{H}$ \\
\hline \multicolumn{15}{|l|}{ POACEAE } \\
\hline Poaceae I & 0.08 & & 0.67 & 0.28 & & & 0.13 & & & & & & $\mathrm{~F}$ & $\mathrm{H}$ \\
\hline Poaceae II & 0.04 & & 1.52 & 1.18 & 0.04 & & 0.18 & 0.09 & & & & & $\mathrm{~F}$ & $\mathrm{H}$ \\
\hline Poaceae III & & 0.16 & & 0.74 & & 3.22 & 0.53 & & & & & & $\mathrm{~F}$ & $\mathrm{H}$ \\
\hline \multicolumn{15}{|l|}{ RUBIACEAE } \\
\hline Borreria verticillata & & & 1.60 & 1.25 & & 0.17 & 2.13 & 1.00 & 0.03 & 0.09 & & 0.05 & $\mathrm{VF}$ & $\mathrm{S}$ \\
\hline Chiococca alba & 0.08 & & & & & & & & & & & & $\mathrm{R}$ & $\mathrm{S}$ \\
\hline Hexasepalum radula & & & 0.82 & 1.00 & & 0.63 & & & & & & 0.32 & $\mathrm{~F}$ & $\mathrm{~S}$ \\
\hline Posoqueria latifolia & 0.23 & 0.02 & & 0.02 & 0.08 & 0.03 & & & & 0.62 & & 0.05 & $\mathrm{VF}$ & $\mathrm{S} / \mathrm{A}$ \\
\hline \multicolumn{15}{|l|}{ RUTACEAE } \\
\hline Citrus & 1.41 & & & 0.07 & & & & & & & & & I & A \\
\hline \multicolumn{15}{|l|}{ SAPINDACEAE } \\
\hline Serjania salzmanniana & 0.98 & & & & & & & 0.03 & & & & & I & $\mathrm{L}$ \\
\hline \multicolumn{15}{|l|}{ SOLANACEAE } \\
\hline Solanum & & & & 0.31 & 1.08 & 13.83 & & 0.67 & & 9.77 & 40.55 & 19.64 & $\mathrm{VF}$ & S \\
\hline \multicolumn{15}{|l|}{ TURNERACEAE } \\
\hline Turnera subulata & & & & & & & & & 0.03 & & & & $\mathrm{R}$ & $\mathrm{S}$ \\
\hline \multicolumn{15}{|l|}{ URTICACEAE } \\
\hline Cecropia & & 0.27 & & & 0.24 & 0.25 & & 38.87 & 49.32 & 0.57 & & & $\mathrm{~F}$ & A \\
\hline Undetermined I & & & & & & & 8.14 & 2.07 & 0.19 & 0.33 & & & $\mathrm{~F}$ & - \\
\hline Undetermined II & & & & & & & & & 0.19 & & & 0.05 & I & - \\
\hline
\end{tabular}

Thirteen pollen types showed frequency values above $10 \%$ in the samples and were present for more than four months during the study period and, therefore, were classified as frequent and very frequent (Table 1). These pollen types are distributed in the following families: Amarantaceae (Alternanthera brasiliana), Anacardiaceae (Anacardium occidentale and Tapirira guianensis), Asteraceae (Aspilia and Baccharis retusa), Cannabaceae (Celtis), Fabaceae (Aeschynomene paniculata and Mimosa pudica), Malpighiaceae (Byrsonima),
Myrtaceae (Eucalyptus), Plantaginaceae (Stemodia foliosa), Urticaceae (Cecropia), and Solanaceae (Solanum). These pollen types were the most representative of the pollen spectrum composition due to the high frequency of occurrence values associated with their wide presence during the study period.

The most representative pollen types in the analyzed samples showed some predominant characteristics (Table 2, Fig 3). The monad dispersion unit was presented in most of the 13 pollen types, except in Mimosa pudica that corresponds to a 
tetrad. Plant species number with tricolporate pollen grains were higher (10). While pantoporate aperture was registered in Alternanthera brasiliana and dipore in Cecropia, it was not possible to observe the apertures in Mimosa pudica. Furthermore, eight types of exine ornamentation was registered, of which the microreticulate exine was recorded in five pollen types. The predominant form of pollen grains was prolate spheroidal, recorded in eight pollen types. Regarding the size of the pollen grains, most of the pollen types were small (9), this size coinciding with the pollen types that presented the highest frequency values: Byrsonima ( 0.05 to $82.79 \%$, which was recorded during the entire study period), Tapirira guianensis (0.92 to 55.65\%), and Cecropia ( 0.24 to $49.32 \%$ ).

Table 2. Palynological description of the most representative pollen types in the composition of pollen samples stored by Tetragonisca angustula (Latreille, 1811) in an area of Atlantic Forest on the northern coast of Bahia. DU (Dispersal unit): M= Monad; T= Tetrad. Size: VS= Very Small; $\mathrm{S}=$ Small; $\mathrm{M}=$ Medium.

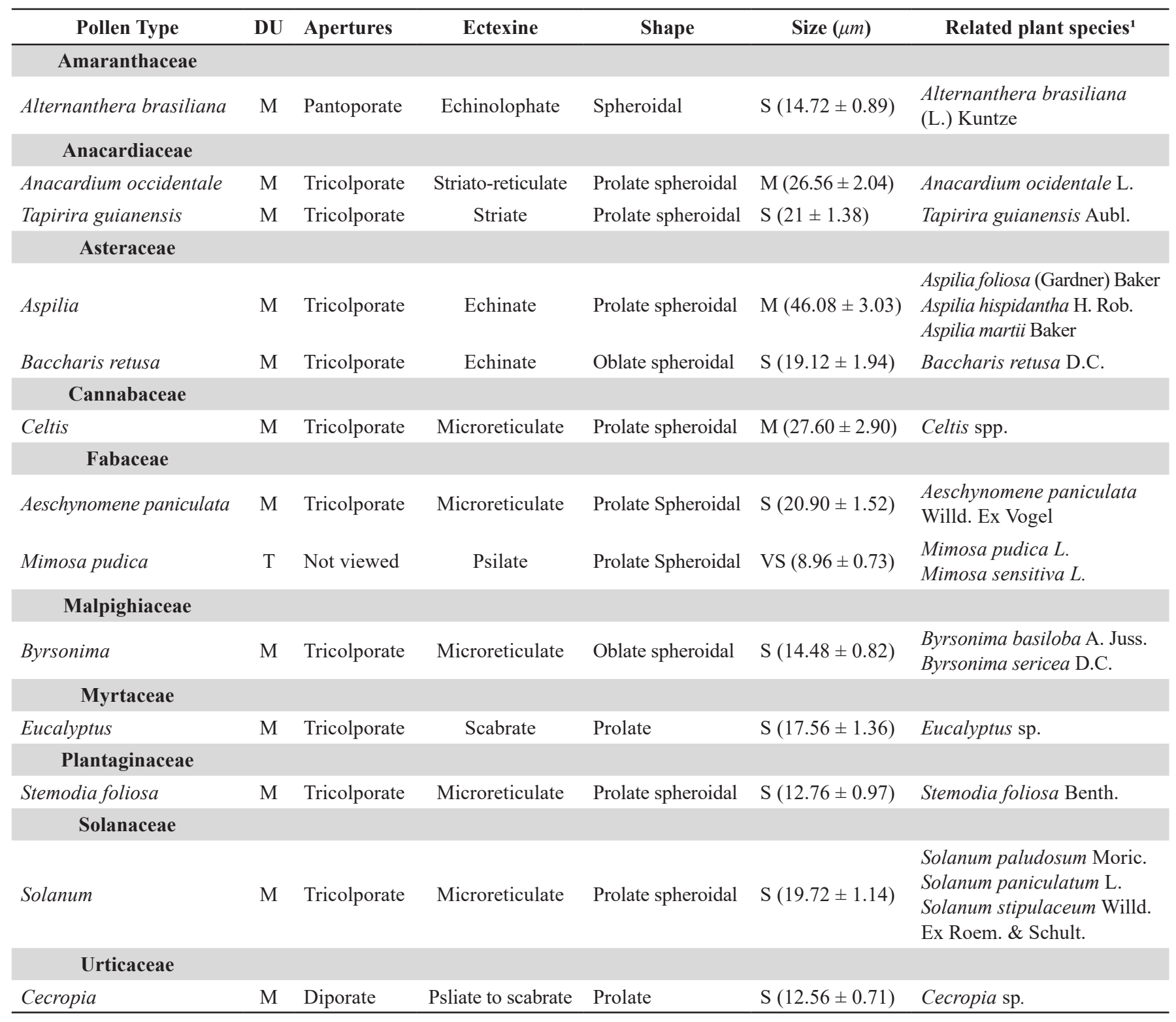

\section{Discussion}

The number of pollen types recognized in the analyzed pollen samples reflects the abundance of plant species that provide trophic resources for the maintenance and survival of T. angustula colonies in an Atlantic Forest area. Previous palynological studies with stingless bee species in an Atlantic Forest area also demonstrated a large number of visited floral sources (Kleinert-Giovannini \& Imperatriz-Fonseca,
1987; Cortopassi-Laurino \& Ramalho, 1988; Carvalho \& Marchini, 1999; Faria et al., 2012), which corroborate the floristic diversity of this biome. Nevertheless, of the total pollen types registered, some of them were not evidenced in the quantitative analysis, which may be related to a secondary contribution to the diet of these bees and being characterized as unattractive pollen sources according to Ramalho et al. (1985) and Imperatriz-Fonseca et al. (1994). Besides, other factors may also contribute to the foraging behavior of bees, 

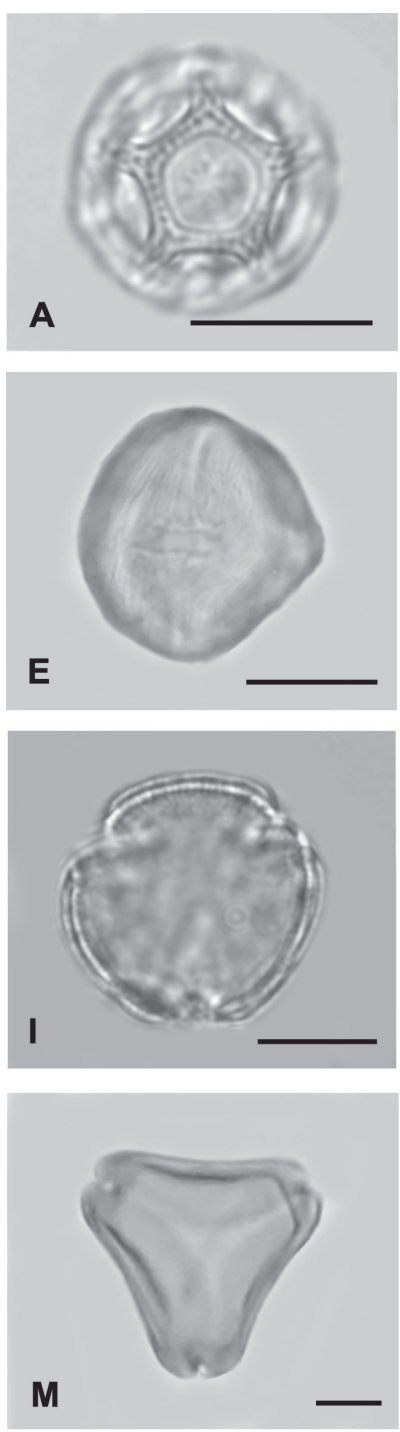
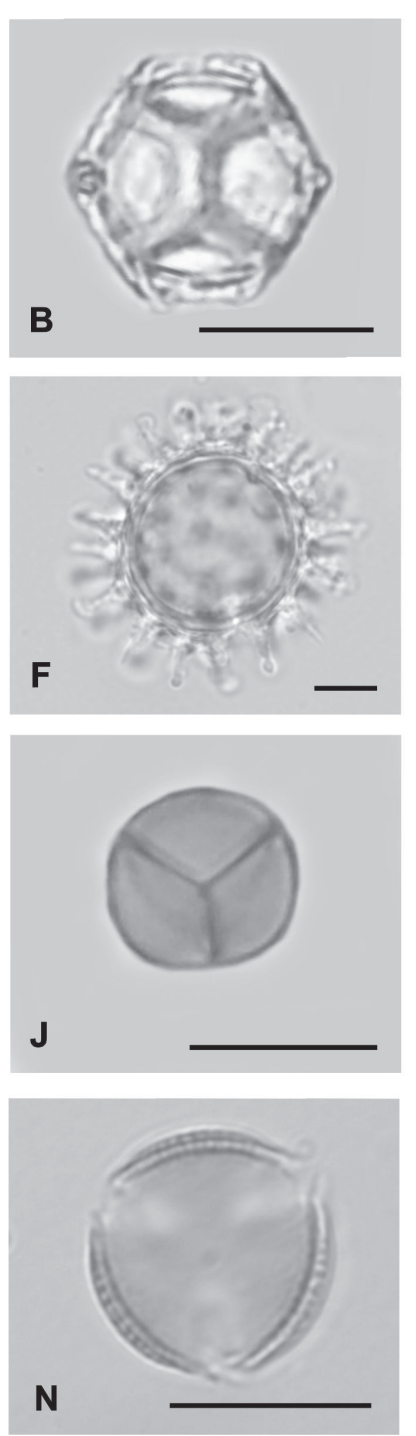
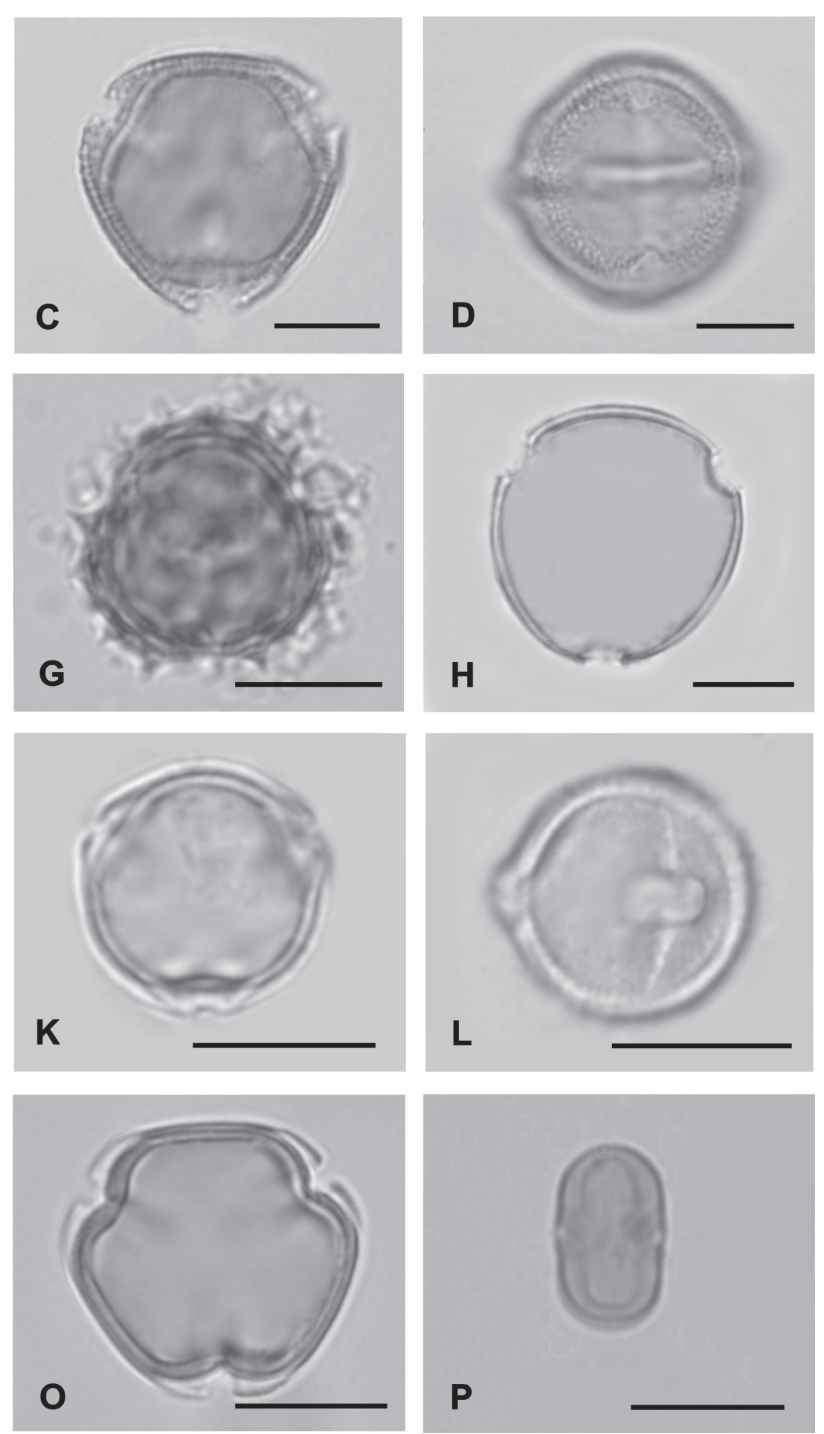

Fig 3. Photomicrographs of pollen types recorded in pollen samples stored by Tetragonisca angustula (Latreille, 1811). Amaranthaceae: A-B. Alternanthera brasiliana - A. Aperture; B. Surface. Anacardiaceae: C-D. Anacardium ocidentale - C. Polar view; D. Equatorial view. E. Tapirira guianensis. Asteraceae: F. Aspilia. G. Baccharis retusa. Cannabaceae: H. Celtis. Fabaceae: I. Aeschynomene paniculata. J. Mimosa pudica. Malpighiaceae: K-L. Byrsonima - K. Polar view; L. Equatorial view. Myrtaceae: M. Eucalyptus. Plantaginaceae: N. Stemodia foliosa. Solanaceae: O. Solanum. Urticaceae: P. Cecropia. Scale bar $10 \mu \mathrm{m}$.

such as blooming period length, foraging action range, and colony size (Kerr et al., 1996; Ramalho et al., 2007).

The frequency of occurrence of pollen types through the study period, in which the majority were classified as very frequent and frequent, is probably related to the floral constancy in the T. angustula foraging pattern, indicating the availability of floral resources throughout the year for colony maintenance.

In the pollen spectrum, there was a predominance of pollen types related to shrubby and arboreal plants. Similar results were found by Rodrigues et al. (2020), who evaluated the pollen resources collected by stingless bees in a fragment of Atlantic forest and reported that arboreal and shrubby species were more intensely and frequently visited. According to Ramalho (2004), stingless bees concentrate their collection efforts in the upper layer of vegetation in the Atlantic Forest environments, searching for massive flowering.
Among the floral sources that were extensively exploited to supply the protein diet of T. angustula, pollen types of the families Fabaceae, Myrtaceae, and Asteraceae were also reported by Iwama and Melhem (1979), Carvalho and Marchini (1999), and Morgado et al. (2011). Thus, the results obtained in our research along with those of these authors, corroborate the importance of these botanical families for the supply of trophic resources, and consequently, for the maintenance of the colonies. In addition, in a study focused on the pollen and nectar sources that are important for stingless bees and africanized bees in neotropical habitats, Ramalho et al. (1990) listed 288 species with an emphasis on 18 genera, seven of which were also recorded in the present study, namely: Baccharis (Asteraceae), Cecropia (Urticaceae), Croton (Euphorbiaceae), Mimosa (Fabaceae), Solanum (Solanaceae), Spondias (Anacardiaceae), and Byrsonima (Malpighiaceae). 
The Eucalyptus pollen type, which showed high frequency values in the analyzed samples, is related to an exotic plant species, which has been reported as dominant or important in the pollen spectrum of honey and pollen loads of stingless bees in previous studies (Kleinert- Giovannini \& Imperatriz-Fonseca, 1987; Ramalho et al., 1990, 1994; Carvalho et al., 2001; Antonini et al., 2006). These data indicate the presence of Eucalyptus monocultures in the northern coast of Bahia, which occupy extensive areas and replace the native vegetation (Andrade \& Oliveira, 2016). It is worth pointing out that pollen grains of some species of Eucalyptus may have a low concentration of essential lipids and amino acids, which negatively influences the longevity of bees and leads to a decrease in their populations (Bell et al., 1983; Manning et al., 2007).

Pollen types considered as the most representative in samples showed a pollen morphology characterized mainly by small monads, unlike the results found by Braga et al. (2012). In a study on the floral resources of $T$. angustula in an Atlantic Forest area in southeastern Brazil, these authors reported significant differences between the pollen morphology of the visited floral sources, mainly in relation to the shape of the pollen grain, since small to very large pollen grains with spheroidal to perprolate shape were registered.

In the present study, small pollen grains belonged to the pollen types that presented the highest frequency values in the samples, of which Byrsonima (Malpighiaceae) and Cecropia (Urticaceae) were also reported by Novais et al. (2014) with frequency values above $45 \%$, being considered as predominant pollen types in samples of pollen sediment stored by $T$. angustula in an area of the Amazon Forest. Cecropia pollen type, although represents an anemophilous plant, is produced by plants in large amounts of pollen, which is of importance for maintaining colonies mainly in periods of pollen scarcity (such as rainy seasons, for example), as stated by Rech and Absy (2011).

According to Vossler (2014), pollen grains classified as small in size are usually found in inconspicuous flowers with short pistils, which is characteristic of a floral morphology adapted to pollination by small to medium-sized bees. This author also states that high frequency values of small pollen grains may be related to the preference of meliponines for small flowers with short pistils, supporting the previously suggested hypothesis of diffuse coevolution between massive flowering trees and meliponines in neotropical environments.

Therefore, the richness of botanical families visited by T. angustula confirms the generalist habit of this Meliponini species, which focus its efforts on the constant foraging of abundant resources, such as plant species with massive blooms in the forest canopy. Our results highlight pollen types related to arboreal and shrubby plant species as important sources of trophic resources for stingless bees, with emphasis on Byrsonima, Tapirira guianensis, and Cecropia, as fundamental species for the protein diet of $T$. angustula in the Atlantic Forest. In addition, herbaceous plant species occasionally contributed in some months throughout the year, which represent a secondary source for $T$. angustula diet.

Through palynological analysis, this research contributed to the knowledge of floral sources that offer trophic resources for T. angustula, pointing out the importance of the preservation of the plant species diversity in the Atlantic Forest for the maintenance and survival of stingless bee colonies.

\section{Acknowledgments}

We are grateful to Msc. R. O. Batista for assisting in the collection of pollen samples and the National Council for Scientific and Technological Development (CNPq) for granting financial resources to the first author. This study was financed in part by the Coordenação de Aperfeiçoamento de Pessoal de Nível Superior - Brasil (CAPES) - Finance Code 001.

\section{Authors Contribution}

BP Bastos - Investigation, formal anaylisis and writing.

LCL Lima - Conceptualization, methodology, supervision and writing.

MC Dórea - Conceptualization, methodology, supervision and writing.

\section{References}

Antonini, Y., Costa, A. Y. \& Martins, R. P. (2006). Floral preferences of a neotropical stingless bee, Melipona quadrifasciata Lepeletier (Apidae: Meliponina) in an urban forest fragment. Brazilian Journal of Biology, 66: 463-471. doi: 10.1590/S1519-69842006000300012.

Antunes, O. T., Calvete, E. O., Rocha, H. C., Nienow, A. A., Cecchetti, D., Riva, E. \& Maran, R. E. (2007). Produção de cultivares de morangueiro polinizadas pela abelha jataí em ambiente protegido. Horticultura Brasileira, 25: 094-099. doi: 10.1590/S0102-05362007000100018

Andrade, M. L. \& Oliveira, G. C. (2016). Monocultura do eucalipto na Bahia: um retrato da apropriação privada da natureza. Cadernos do CEAS, Salvador, 237: 294-326. doi: 10.25247/2447-861X.2016.n237.

Bell, R., Thornber, E. J., Seet, J. L. L., Groves, M. T., Ho, N. P. \& Bell, D. T. (1983). Composition and protein quality of honeybee-collected pollen of Eucalyptus marginata and Eucalyptus calophylla. Journal of Nutrition, 113: 2479-2484. doi: $10.1093 / \mathrm{jn} / 113.12 .2479$

Burkle, L. A. \& Alarcón, R. (2011). The future of plantpollinator diversity: understanding interaction networks across time, space, and global change. American Journal of Botany, 98: 528-538. doi: 10.3732/ajb.1000391

Braga, J.A., Sales, E.O., Neto, J. S., Conde, M. M., Barth, O. M. \& Lorenzon, M. C. (2012). Floral sources to Tetragonisca angustula (Hymenoptera: Apidae) and their pollen 
morphology in a Southeastern Brazilian Atlantic Forest. Revista de Biologia Tropical, 60: 1491-1501. doi: 10.1590/ S0102-33062011000400021

Carvalho, C.A.L. \& Marchini, L.C. (1999). Tipos polínicos coletados por Nannotrigona testaceicornis e Tetragonisca angustula (Hymenoptera, Apidae, Meliponinae). Scientia Agricola, 56: 717-722. doi: 10.1590/S0103-90161999000300029

Carvalho, C. A. L., Moreti, A. C. C. C., Marchini, L. C., Alves, R. M. O. \& Oliveira, P. C. F. (2001). Pollen spectrum of honey of "uruçu" bee (Melipona scutellaris Latreille, 1811). Revista Brasileira de Biologia, 61: 63-67. doi: 10.1590/ S0034-71082001000100009

Cortopassi-Laurino, M. \& Ramalho, M. (1988). Pollen harvest by africanized Apis mellifera and Trigona spinipes in São Paulo: botanical and ecological views. Apidologie, 19: 1-24. doi: 10.1051/apido:19880101

De Klerk, P. \& Joosten, H. (2007). The difference between pollen types and pollen taxa: a plea for clarity and scientific freedom. Quaternary Science Journal, 56: 24-33. doi: 10.3285/ eg.56.3.02, 2007

Erdtman, G. (1960). The acetolysis method: a revised description. Svensk Botanisk Tidskrift, 39: 561-564.

Faria, L.B., Aleixo, K.P., Garófalo, C.A., ImperatrizFonseca, V.L. \& Silva, C.I. (2012) Foraging of Scaptotrigona aff. depilis (Hymenoptera, Apidae) in an urbanized area: seasonality in resource availability and visited plants. Psyche: Article ID 630628. doi: $10.1155 / 2012 / 630628$

Giannini, T. C., Acosta, A. L., Garófalo, C. A., Saraiva, A. M., Alves-dos-Santos, I. \& Imperatriz-Fonseca, V. L. (2012). Pollination services at risk: bee habitats will decrease owing to climate change in Brazil. Ecological Modelling, 244: 127131. doi: 10.1007/s13592-014-0316-z.

Giannini, T. C., Boff, S., Cordeiro, G. D., Cartolano, E. A., Veiga, A. K., Imperatriz-Fonseca, V. L. \& Saraiva, A. M. (2014). Crop pollinators in Brazil: a review of reported interactions. Apidologie, 46: 209-223. doi: 10.1007/s13592-014-0316-Z

Giannini, T. C., Cordeiro, G. D, Freitas, B. M., Saraiva, A. M. \& Imperatriz-Fonseca, V. L. (2015). The dependence of crops for pollinators and the economic valeu of pollination in Brazil. Journal of Economic Entomology, 108: 849-857. doi: $10.1093 /$ jee/tov093

Imperatriz-Fonseca, V.L., Ramalho, M. \& Kleinert-Giovannini, A. (1994). Abelhas sociais e flores: análise polínica como método de estudo, Pp. 17-30. In: Pirani, J.R., CortopassiLaurino, M. (coord). Flores e Abelhas em São Paulo. São Paulo, Edusp/ Fapesbp.

Iwama, S. \& Melhem, T. S. (1979). The pollen spectrum of the honey of Tetragonisca angustula angustula Latreille (Apidae, Meliponinae). Apidologie, 10: 275-295. doi: 10.1051/apido:19790305
Jesus, N. G., Almeida, G. S. S. \& Fonseca, M. R. (2017). Diversidade florística de dois remanescentes de Floresta Ombrófila Densa. In: Nunes, J. M. C \& Matos, M. R. B. M (Orgs.). Litoral norte da Bahia: caracterização ambiental, biodiversidade e conservação. Salvador: EDUFBA, 2017, p. 157-170.

Jones, G. D. \& Bryant Jr., V.M. (1996). Melissopalynology. In: Jansonius, J. \& McGregor, P.C. (eds.). Palynology: principles and applications. Salt Lake City, American Association of Stratigraphic Palynologists Foudation. v. 3.

Joosten, H. \& De Klerk, P. (2002). What's in a name? Some thoughts on pollen classification, identification, and nomenclature in Quaternary palynology. Review of Palaeobotany and Palynology, 122: 29-45. doi: 10.1016/ S0034-6667(02)00090-8

Kerr, W.K., Carvalho, G.A. \& Nascimento, V.A. (1996). Abelha uruçu: biologia, manejo e conservação. Paracatu: Acangaú.

Kerr, W. E. (1997). A importância da meliponicultura para o país. Biotecnologia, Ciência e Desenvolvimento, 1: 42-44.

Kleinert-Giovannini, A. \& Imperatriz-Fonseca, V. L. (1987). Aspects of the trophic niche of Melipona marginata marginata Lepeletier (Apidae, Meliponinae). Apidologie, 18: 69-100. doi: 10.1051/apido:19870107

Louveaux, J., Maurizio, A. \& Vorwohl, G. (1978). Methods of melissopalynology. Bee World, 59: 139-157. doi: 10.1080/ 0005772X.1978.11097714

Manning, R., Rutkay, A., Eaton, L. \& Dell, B. (2007). Lipidenhanced pollen and lipid-reduced flour diets and their effect on the longevity of honey bees (Apis mellifera L.). Australian Journal of Entomology, 46: 251-257. doi: 10.1111/j.14406055.2007.00598.x

Melhem, T.S., Makino, H., Silvestre, M.S.F., Cruz, M.A.V. \& Jung-Mendaçolli, S. (1984). Planejamento para a elaboração da "Flora Polínica da Reserva do Parque Estadual das Fontes do Ipiranga (São Paulo, Brasil)”. Hoehnea, 11: 1-7.

Michener, C.D. (2007). The bees of the world. 2nd. ed. The Johns Hopkins University Press, Baltimore, 953p.

Morgado, L. N., Andrade, R. C., Lorenzon, M. C. A. \& Gonçalves-Esteves, V. (2011). Padrão polínico utilizado por Tetragonisca angustula Latreille (Apidae: Meliponina). Nota científica. Acta Botanica Brasilica, 25: 348-354. doi: 10.1590/ S0102-33062011000400021

Novais, J. S., Garcêz, A. C. \& Santos, F. A. R. (2014). Comparative pollen spectra of Tetragonisca angustula (Apidae, Meliponini) from the Lower Amazon (N Brazil) and caatinga (NE Brazil). Apidologie, 46: 417-431. doi: 10.1007/ s13592-014-0332-z

Oliveira- Filho, A. T. \& Fontes, M. A. L. (2000). Patterns of floristic differentiation among Atlantic forest in Southeastern 
Brazil and the influence of climate. Biotropica, 32: 793-810. doi: 10.1111/j.1744-7429.2000.tb00619.x

Pedro, S. R. M. (2014). The stingless bee fauna in Brazil (Hymenoptera: Apidae). Sociobiology, 61: 348-354. doi: 10.13102/sociobiology.v61i4.348-354

Potts, S.G., Imperatriz-Fonseca, V., Ngo, H.T., Aizen, M.A., Biesmeijer, J.C., Breeze, T.D, Dicks, L. V, Garibaldi, L. A; Hill, R, Settele, J. \& Vanbergen, A. J. (2016). Safeguarding pollinators and their values to human well-being. Nature, 540: 220-229. doi: 10.1038/nature20588

Punt, W., Hoen, P. P., Blackmore, S., Nilson, S. \& Le Thomas, A. (2007). Glossary of pollen and spore terminology. Review of Palaeobotany and Palynology, 143: 1-81. doi: 10.1016/j. revpalbo.2006.06.008

Ramalho, M. (2004). Stingless bees and mass flowering trees in the canopy of Atlantic Forest: a tight relationship. Acta Botanica Brasilica, 18: 37-47. doi: 10.1590/S010233062004000100005

Ramalho, M., Imperatriz-Fonseca, V.L., Kleinert-Giovannini, A. \& Cortopassi-Laurino, M. (1985). Exploitation of floral resources by Plebeia remota Holmberg (Apidae, Meliponinae). Apidologie, 16: 307-330. doi: 10.1051/apido:19850306

Ramalho, M., Kleinert-Giovannini, A. \& Imperatriz-Fonseca, V. L. (1990). Important bee plants for stingless bees (Melipona and Trigonini) and Africanized honeybees (Apis mellifera) in neotropical habitats: a review. Apidologie, 21: 469-488. doi: 10.1051/apido:19900508

Ramalho, M., Giannini, T. C., Malagodi-Braga, K. S. \& Imperatriz-Fonseca, V. L. (1994). Pollen harvest by stingless bee forragers (Hymenoptera, Apidae, Meliponinae). Grana: 33: 239-244. doi: 10.1080/00173139409429005
Ramalho, M., Silva, M. D. \& Carvalho, C. A. L. (2007). Dinâmica de uso de fontes de pólen por Melipona scutellaris Latreille (Hymenoptera, Apidae): uma análise comparativa com Apis mellifera L. (Hymenoptera, Apidae), no domínio Tropical Atlântico. Neotropical Entomology, 36: 38-45. doi: 10.1590/S1519-566X2007000100005.

Rech, A.R. \& Absy, M.L. (2011). Pollen storages in nests of bees of the genera Partamona, Scaura and Trigona (Hymenoptera, Apidae). Revista Brasileira de Entomologia, 55: 361-372. doi: 10.1590/S0085-56262011005000026

Rodrigues, C. S., Ferasso, D. C., Mossi, A. J., \& Coelho, G. C. (2020). Pollen resources partitioning of stingless bees (Hymenoptera: Apidae) from the southern Atlantic forest. Acta Scientiarum. Biological Sciences, 42: e48714. doi: 10.4025/ actascibiolsci.v42i1.48714

Salgado-Labouriau, M. L. (1973). Contribuição à Palinologia dos Cerrados. Rio de Janeiro: Editora Academia Brasileira de Ciências, 291p.

Souza, R. R., Abreu, V. H. R. \& Novais, J. S. (2018). Melissopalynology in Brazil: a map of pollen types and published productions between 2005 and 2017. Palynology, 43: 690-700. doi: 10.1080/01916122.2018.1542355

Superintendência de Estudos Econômicos e Sociais da Bahia. (2018). Estatísticas dos Municípios Baianos. Available at: http://www.sei.ba.gov.br/index.php?option=com_wrapper\&vi ew=wrapper\&Itemid=266. Acesso em 25 de agosto de 2018 .

Vergeron, P. (1964). Interpretation statistique des resultats en matiere d'analyse pollinique des miel. Les Annales de l'Abeille, 7: 349-364. Available at: https://hal.archivesouvertes.fr/hal-00890207

Vossler, F. G. (2014). Small pollen grain volumes and sizes dominate the diet composition of three South American subtropical stingless bees. Grana, 54: 68-81. doi: 10.1080/00173134.2014.932838. 